\title{
Decreasing cytosolic translation is beneficial to yeast and human Tafazzin-deficient cells
}

\author{
Maxence de Taffin de Tilques ${ }^{1, \$}$, Jean-Paul Lasserre ${ }^{1, \$, *}$, François Godard ${ }^{1}$, Elodie Sardin ${ }^{1}$, Marine Bouhier ${ }^{1}$, \\ Marina Le Guedard ${ }^{2,3}$, Roza Kucharczyk ${ }^{4}$, Patrice X. Petit ${ }^{5}$, Eric Testet $^{2}$, Jean-Paul di Rago ${ }^{1}$, Déborah \\ Tribouillard-Tanvier ${ }^{1, \#, *}$ \\ ${ }^{1}$ Institut de Biochimie et Génétique Cellulaires, CNRS UMR 5095, Université de Bordeaux, 1 rue Camille Saint-Saëns, 33077 Bordeaux \\ cedex, France. \\ ${ }^{2}$ Laboratoire de Biogenèse Membranaire, CNRS UMR 5200, Université de Bordeaux, INRA Bordeaux Aquitaine, Villenave d'Ornon, \\ France. \\ ${ }^{3}$ LEB Aquitaine Transfert-ADERA, FR-33883 Villenave d'Ornon, Cedex, France. \\ ${ }^{4}$ Institute of Biochemistry and Biophysics, Polish Academy of Sciences, Warsaw, Poland. \\ ${ }^{5}$ CNRS FR3636 Fédération de recherché en Neuroscience, Université Paris-Descartes, 45, rue des Saints-Pères, 75006 Paris, France. \\ \# Research associate from INSERM. \\ $\$$ These authors contributed equally. \\ * Corresponding Authors: \\ Déborah Tribouillard-Tanvier, Phone: +33 5569990 39, Fax: +33 559990 51; E-mail: deborah.tribouillard-tanvier@ibgc.cnrs.fr; \\ Jean-Paul Lasserre, Phone: +33 559990 39, Fax: +33 569990 51; E-mail: jean-paul.lasserre@ibgc.cnrs.fr
}

\begin{abstract}
Cardiolipin (CL) optimizes diverse mitochondrial processes, including oxidative phosphorylation (OXPHOS). To function properly, $\mathrm{CL}$ needs to be unsaturated, which requires the acyltransferase Tafazzin (TAZ). Loss-offunction mutations in the TAZ gene are responsible for the Barth syndrome (BTHS), a rare X-linked cardiomyopathy, presumably because of a diminished OXPHOS capacity. Herein we show that a partial inhibition of cytosolic protein synthesis, either chemically with the use of cycloheximide or by specific genetic mutations, fully restores biogenesis and the activity of the oxidative phosphorylation system in a yeast BTHS model (taz1 $\Delta)$. Interestingly, the defaults in $\mathrm{CL}$ were not suppressed, indicating that they are not primarily responsible for the OXPHOS deficiency in $\operatorname{taz1\Delta }$ yeast. Low concentrations of cycloheximide in the picomolar range were beneficial to TAZ-deficient HeLa cells, as evidenced by the recovery of a good proliferative capacity. These findings reveal that a diminished capacity of $\mathrm{CL}$ remodeling deficient cells to preserve protein homeostasis is likely an important factor contributing to the pathogenesis of BTHS. This in turn, identifies cytosolic translation as a potential therapeutic target for the treatment of this disease.
\end{abstract}

doi: $10.15698 / \operatorname{mic} 2018.05 .629$ Received originally: 03.11.2017; in revised form: 01.02.2018, Accepted 05.02.2018, Published 18.02.2018.

Keywords: mitochondrial disease, oxidative phosphorylation, Barth syndrome, cytosolic protein synthesis, cycloheximide; cardiolipin remodeling.
Abbreviations:
BTHS - Barth syndrome,
$\mathrm{CHX}-$ cycloheximide,
$C L-$ cardiolipin,
OXPHOS-oxidative phosphorylation,
ROS - reactive oxygen species,
WT-wild type.

\section{INTRODUCTION}

The Barth Syndrome (BTHS) is a rare X-linked recessive mitochondrial disorder that is characterized by cardiac and skeletal myopathies, growth retardation, hypocholesterolemia, increased urine levels of 3-methylglutaconic acid and high susceptibility to bacterial infections, due to cyclic neutropenia [1-3]. This disease is caused by mutations in Tafazzin, a mitochondrial protein involved in the remodeling of cardiolipin (CL). This phospholipid is mainly found in mitochondria, [4-10] where it optimizes numerous pro- cesses including oxidative phosphorylation (OXPHOS) [11 13], fusion [14], fission [15, 16], protein import [17, 18], iron-sulfur cluster biogenesis [19], mitophagy [20-23], apoptosis [7, 23-28] and the transport of metabolites across the mitochondrial inner membrane $[6,17,29-36]$. Tafazzin is an acyltransferase required for the maintenance of unsaturated carbon-carbon bonds in CL fatty acyl chains $[1,37-41]$. Loss-of-function mutations in Tafazzin lead to reduced levels of unsaturated $\mathrm{CL}$ and the accumulation of $\mathrm{CL}$ species with an incomplete set of fatty acyl chains (such 
as monolysocardiolipin, $\mathrm{MLCL}$ ) [42-44]. This in turn results in multiple mitochondrial alterations that ultimately compromise the OXPHOS capacity [24, 45-48].

Simple model organisms such as Saccharomyces cerevisiae or baker's yeast are an important resource for the study of mitochondrial diseases. Mitochondria from this single-celled fungus and humans show many similarities [49-53]. Being easily amenable to genetic manipulation of mitochondrial function [54,55], and owing to the ability of yeast to survive the loss of oxidative phosphorylation; yeast models of human mitochondrial diseases can be easily created and kept alive when provided with fermentable substrates [56, 57]. The common respiratory growth defect of these models enables large-scale screening of genetic and pharmacological suppressors [57-59]. Yeast has in this way already pointed to several potential druggable therapeutic intervention points, such as the oxodicarboxylic acid carrier [60] and mitochondrial protein import [61], among others.

Herein we report that reducing cytosolic protein synthesis preserves OXPHOS in CL remodeling deficient yeast and improves the growth rate and viability of human HeLa cells lacking Tafazzin. This study sheds new light on the pathogenesis of BTHS and identifies cytosolic protein synthesis as a potential intervention point for the treatment of the disease.

\section{RESULTS}

Decreasing cytosolic protein synthesis improves respiratory growth of $\operatorname{taz} 1 \Delta$ yeast

We [60] and others [62] showed that yeast cells lacking the gene encoding Taz1p $(\operatorname{taz} 1 \Delta)$ grow poorly on respiratory carbon sources at $36^{\circ} \mathrm{C}$, compared to the wild-type (WT) $\mathrm{TAZ1}^{+}$strain. Using a drug screening procedure we previously described [58], we found that cytosolic protein synthesis inhibitors such as, cycloheximide (hereafter abbreviated as $\mathrm{CHX)}$, anisomycin and emetine suppressed this phenotype in a dose-dependent manner. In the tests shown in Fig. 1A, taz1 $\Delta$ cells freshly grown by fermentation in glucose were spread on plates containing ethanol (respiratory carbon source) and then exposed to paper disks spotted with the drugs dissolved in DMSO. After five days of incubation at $36^{\circ} \mathrm{C}$, halos of enhanced growth appeared around the filters, whereas DMSO alone had no effect. In this assay the compounds diffused into the medium, explaining why growth was improved only at some distance around the filters, below which it was totally absent due to a too high concentration of the protein synthesis inhibitors. $\mathrm{CHX}$ was active at 20-30 fold lower concentrations compared to anisomycin and emetine (Fig. 1A). The optimal rescuing concentration range of $\mathrm{CHX}$ was determined by growth tests in liquid media containing $2 \%$ ethanol and $0.5 \%$ galactose, at $36^{\circ} \mathrm{C}$. After consumption of the galactose, which is a fermentable substrate, growth of taz1 $\Delta$ yeast was much less efficient compared to the WT, owing to its failure to properly express mitochondrial function (Fig. 1B). The best growth improvement of $\operatorname{taz} 1 \Delta$ yeast was observed in the presence of $10 \mathrm{nM} \mathrm{CHX}$. At this concentra- tion, growth of the wild type was unaffected (Fig. 1B). Pulse labeling of proteins with $\mathrm{S}^{35}$-methionine and $\mathrm{S}^{35}$. cysteine revealed that the rate of cytosolic protein synthesis was decreased by about $50 \%$ in $\operatorname{taz} 1 \Delta$ yeast grown in the presence of $10 \mathrm{nM} \mathrm{CHX}$, in comparison to the WT (Fig. 1C). Interestingly, cytosolic translation was already decreased in the mutant grown in the absence of the drug by about $35 \%$, possibly as a means to attenuate a protein stress induced by a lack in CL remodeling (see below).

If $\mathrm{CHX}$ is a well-known inhibitor of cytosolic translation, one cannot exclude that it has other effects in cells that could be responsible for the improved respiratory growth of $\operatorname{taz} 1 \Delta$ yeast. We therefore tested the effects on $\operatorname{taz} 1 \Delta$ yeast of null mutations in the genes REI1 and RPL6B that are known to partially inhibit cytosolic protein synthesis by $20 \%$ and $30 \%$ respectively $[63,64]$. The double mutants $\operatorname{taz} 1 \Delta$ rei1 $\Delta$ and $\operatorname{taz} 1 \Delta$ rpl $6 b \Delta$ grew efficiently on respiratory carbon sources (Fig. 1D, E), and showed a $50 \%$ drop in the rate of protein synthesis (Fig. 1C). These data confirmed that the beneficial effect of $\mathrm{CHX}$ in $\operatorname{taz} 1 \Delta$ yeast resulted from a decreased rate of protein synthesis.

\section{Decreasing cytosolic protein synthesis improves mtDNA maintenance in taz1 $\Delta$ yeast}

We previously showed that $\operatorname{taz} 1 \Delta$ yeast grown by fermentation at $28^{\circ} \mathrm{C}$, i.e. in conditions where the presence of functional mtDNA is not indispensable, has an increased propensity to produce $\rho / \rho^{0}$ cells issued from large deletions in the mitochondrial genome $(60 \%$ vs $5 \%$ in the WT) [60]. The double mutants $\operatorname{taz} 1 \Delta$ rei1 $\Delta$ and taz1 $\Delta$ rpl6b $\Delta$ produced five to ten times less $\rho \% \rho^{0}$ cells than $\operatorname{taz} 1 \Delta$ yeast in glucose cultures (Fig. 1F). Thus, partially decreasing cytosolic translation preserves a proper maintenance of mtDNA in $\mathrm{CL}$ deficient yeast cells.

\section{Reducing cytosolic translation does not restore CL remodel- ing in taz1 $1 \Delta$ yeast}

As reported [39, 60, 62], mitochondria from $\operatorname{taz} 1 \Delta$ yeast, compared to those from the WT, have $50 \%$ less CL, a 2 -fold higher content in phosphatidylinositol (PI), whereas phosphatidylethanolamine (PE) and phosphatidylcholine (PC) accumulated normally (Fig. 2A). Additionally, the remaining $\mathrm{CL}$ species are less unsaturated as suggested by the decreased levels in oleic acid chains (C18:1) and increased stearic (C18:0) and palmitic (C16:0) groups compared to $\mathrm{CL}$ molecules extracted from the WT (Fig. 2B). Strains taz1 rei1 $\Delta$ and taz1 $\Delta$ rpl6b showed very similar phospholipid profiles (Fig. 2A, B), indicating that mitochondrial function recovery in $\operatorname{taz} 1 \Delta$ yeast upon partial inhibition of cytosolic translation did not result from an enhanced production of mature $\mathrm{CL}$ species.

Partially decreasing cytosolic protein synthesis fully restores OXPHOS in taz1 $1 \mathrm{yeast}$

As we have shown [60], the reduced ability of $\operatorname{taz} 1 \Delta$ yeast to grow at $36^{\circ} \mathrm{C}$ in $2 \%$ ethanol $+0.5 \%$ galactose (shown in Fig. 1B) correlated with a decreased rate of oxygen con- 
A

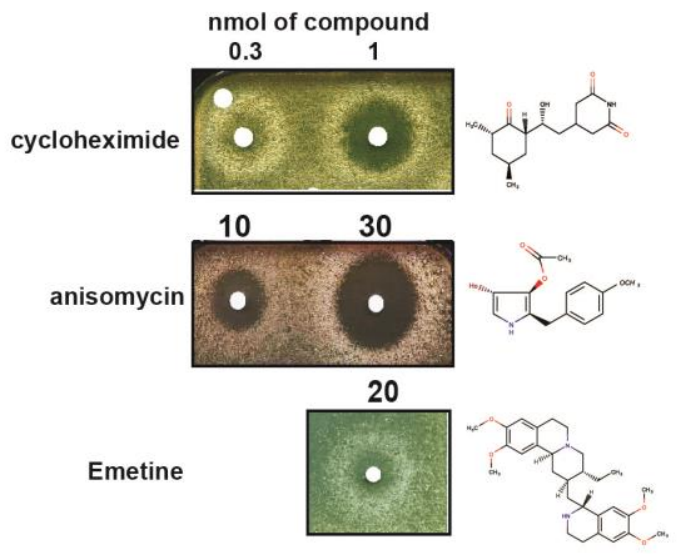

C

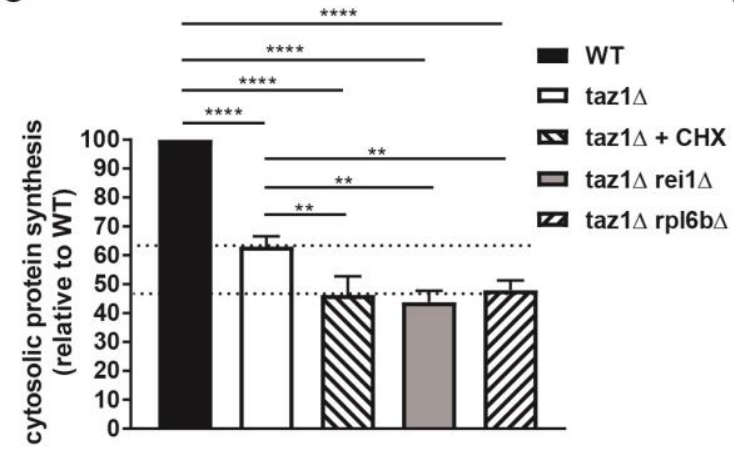

E

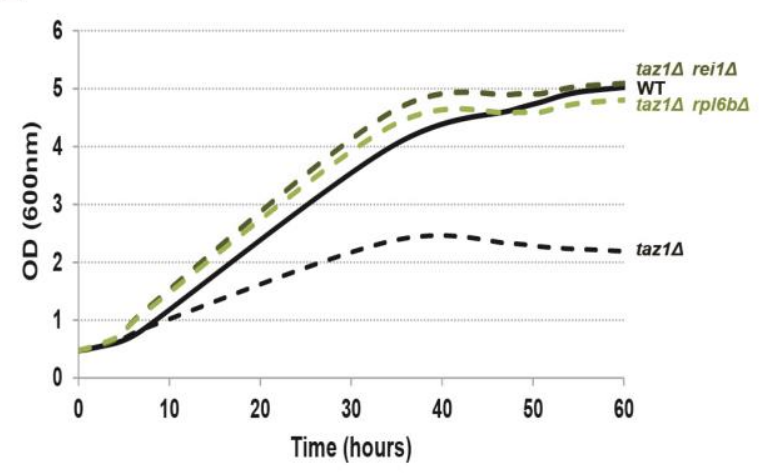

$\mathbf{F}$
B

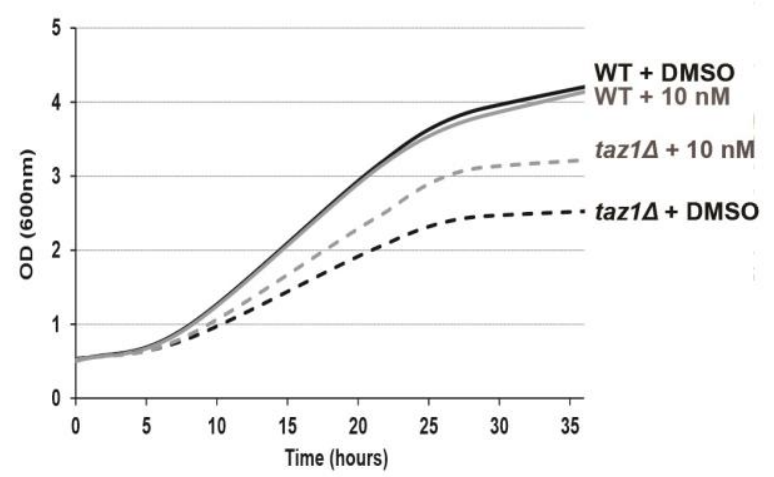

D

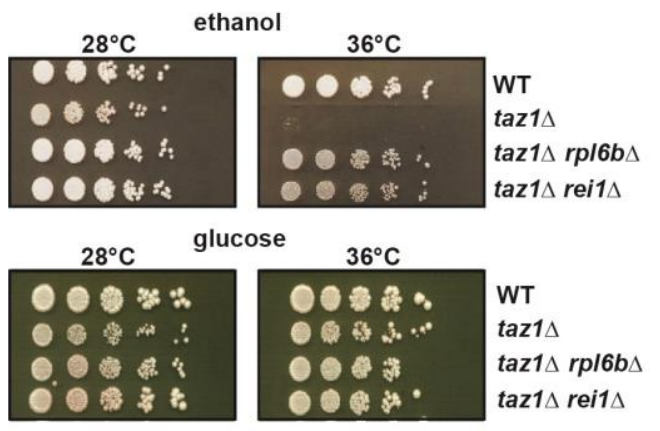

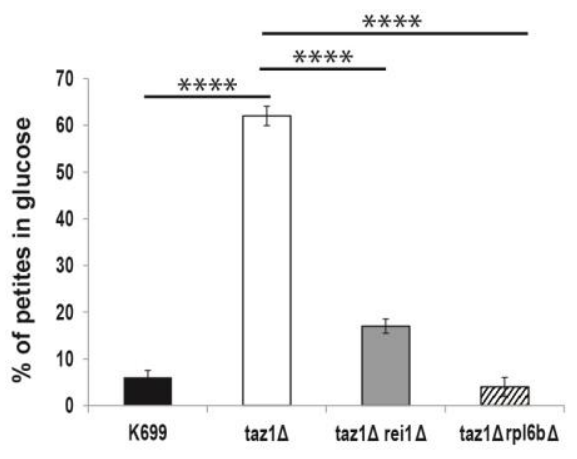

FIGURE 1: Partially decreasing cytosolic translation in Taffazin-deficient (taz1 $\Delta$ ) yeast improves respiration-dependent growth and mtDNA maintenance. (A) $\operatorname{taz} 1 \Delta$ yeast cells were spread as dense layers onto rich ethanol solid media and then exposed to sterile filters spotted with cycloheximide, anisomycin or emetine (dissolved in DMSO). The plates were scanned after 5 days of incubation at $36^{\circ} \mathrm{C}$. The filter at the top left was spotted with DMSO alone to provide a negative control. (B) Determination in liquid cultures of $\mathrm{CHX}$ concentrations that optimally rescue taz1 $\Delta$ yeast. Complete synthetic media (CSM) containing $0.5 \%$ galactose $+2 \%$ ethanol supplemented or not with $\mathrm{CHX}$ at the indicated concentrations were inoculated with WT and taz1 $\mathrm{C}$ cells pre-grown in CSM containing $2 \%$ glucose at $28^{\circ} \mathrm{C}$. The cultures were performed at $36^{\circ} \mathrm{C}$ and cells densities $\left(\mathrm{OD}_{600 \mathrm{~nm}}\right)$ taken over a period of 36 hours. (C) Rate of cytosolic protein synthesis. Total proteins and mitochondrial proteins were labeled with a mixture of $\left[{ }^{35} \mathrm{~S}\right]$-methionine and $\left[{ }^{35} \mathrm{~S}\right]$-cysteine for 20 min in whole cells from wild type, taz1 $\Delta$ rei1 1 , taz $1 \Delta$ rpl $6 b \Delta$ and $\operatorname{taz} 1 \Delta$ yeast grown for 24 hours in rich $0.5 \%$ galactose $+2 \%$ ethanol at $36^{\circ} \mathrm{C}$, and taz $1 \Delta$ cells grown in the same conditions in presence of $10 \mathrm{nM}$ cycloheximide (CHX). After the labeling reactions, total protein extracts were prepared and separated by SDS-PAGE on a $12 \%$ polyacrylamide gel (75 $\mu \mathrm{g}$ per lane). The gels were dried and analyzed with a Phosphorlmager. Quantification was performed using Image J. Data are expressed in \% relative to the WT $(n=3)$. The shown data are cytosolic protein synthesis rates (total minus mitochondrial protein synthesis rates). Statistical analysis was done with Tukey's test

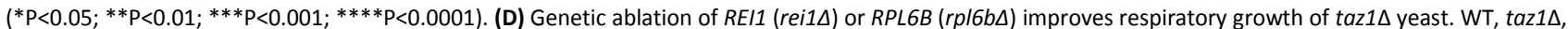
taz1 $\Delta$ rei1 $\Delta$ and taz $1 \Delta r$ r $/ 6 b \Delta$ cells freshly grown at $28^{\circ} \mathrm{C}$ in rich glucose were serially diluted and spotted onto rich ethanol and glucose plates. The plates were scanned after 4 days of incubation at the indicated temperature. (E) Growth of WT, $\operatorname{taz} 1 \Delta$, $\operatorname{taz} 1 \Delta$ rei1 $\Delta$ and taz1 $\operatorname{rpl} 6 \mathrm{~b} \Delta$ strains in liquid complete synthetic media containing $0.5 \%$ galactose $+2 \%$ ethanol at $36^{\circ} \mathrm{C}$. The cultures were inoculated with cells grown in CSM containing $2 \%$ glucose at $28^{\circ} \mathrm{C}$. The cultures were

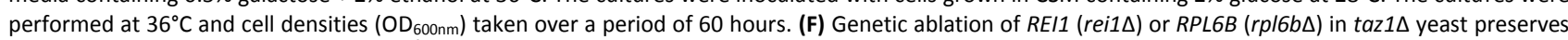
mtDNA maintenance. Proportions of $\rho \% \rho^{0}$ cells produced in glucose cultures at $28^{\circ} \mathrm{C}$ of strains WT, $\operatorname{taz} 1 \Delta, \operatorname{taz} 1 \Delta$ rei $\Delta$, and taz1 $\operatorname{rp} / 6 b \Delta$ were determined using the procedure described in [60] $(n=3)$. Data are expressed in \% relative to the WT and were statistically analyzed using Tukey's test $(* P<0.05 ; * * P<0.01$; $* * * \mathrm{P}<0.001)$. 
sumption and diminished levels of key components involved in the transfer of electrons to oxygen, including complexes II-IV and cytochrome $c$. Accumulation of these proteins (Fig. 3A, B) and oxygen consumption measured with either NADH or Ascorbate-TMPD as electron donors were substantially improved after eliminating REI1 or $R P L 6 B$ (Fig. 3C) or growing $\operatorname{taz} 1 \triangle$ yeast in the presence of $10 \mathrm{nM} \mathrm{CHX} \mathrm{(Fig.} \mathrm{3D).} \mathrm{Consequently,} \mathrm{the} \mathrm{rate} \mathrm{of} \mathrm{mitochon-}$ drial ATP synthesis was restored to almost normal levels (Fig. 3E).

These observations were corroborated by monitoring changes in mitochondrial membrane potential $(\Delta \Psi)$ with Rhodamine 123. As we showed [60], adding ADP to respiring $\operatorname{taz} 1 \Delta$ mitochondria did not decrease $\Delta \Psi$ due to their poor capacity to synthesize ATP. Consistent with their good ability to produce ATP, those from strains $\operatorname{taz} 1 \Delta$ rei1 $\Delta$ and taz1 $\Delta$ rpl6bD efficiently responded to ADP as WT mitochondria (Fig. 4). Furthermore, after a subsequent addition of $K C N$, to block the respiratory chain, $\Delta \Psi$ collapsed in one single rapid phase in $\operatorname{taz} 1 \Delta$ mitochondria, whereas a residual potential was preserved in those from taz1 $1 \Delta$ rei1 $\Delta$ and taz1 1 rpl6b $\Delta$ and WT yeasts. This residual potential is due to the pumping of protons by ATP synthase, coupled by the hydrolysis of the ATP that accumulated in the mitochondrial matrix during phosphorylation of the added ADP, as evidenced by the loss of this potential by inhibiting ATP synthase with oligomycin (Fig. 4).

Taken together, these observations demonstrate that partially decreasing cytosolic translation preserves the biogenesis and activity of the OXPHOS system in $\mathrm{CL}$ remodeling deficient yeast.

Partially decreasing cytosolic protein synthesis suppresses the enhanced production of ROS in taz1 $1 \triangle$ yeast

Defects in the mitochondrial respiratory chain often result in a higher production/accumulation of reactive oxygen species (ROS) owing to an enhanced diversion of electrons from their normal pathway to oxygen, which was observed in $\mathrm{CL}$ remodeling deficient cells [65]. Thus, it was expected that $\operatorname{taz} 1 \triangle$ yeast should produce less ROS after deleting $R E I 1$ or RPL6B or during growth in the presence of $10 \mathrm{nM}$ $\mathrm{CHX}$, which was indeed observed (Fig. 5).

\section{Decreasing cytosolic protein synthesis is also beneficial to tafazzin-deficient human cells}

We aimed to understand whether partially decreasing cytosolic translation could also benefit human cells lacking Tafazzin. To this end, we used our previously described HeLa cells, in which the TAZ gene was knocked down by RNA interference (shTaz1) and two control cell lines, shWT1 and shTaz1R in which the expression of TAZ1 was not inhibited. As reported, ShTaz1 poorly accumulates Tafazzin, is defective in $\mathrm{CL}$ maturation, has a reduced capacity to associate respiratory chain complexes into 'respirasomes', produces abnormally enlarged cells and has a higher content in mitochondria compared to shWT1 and shTaz1R, as do cells from BTHS patients $[24,48,66]$.

Herein we report that ShTaz1 cells proliferate four times slower and die more rapidly, in comparison to
A

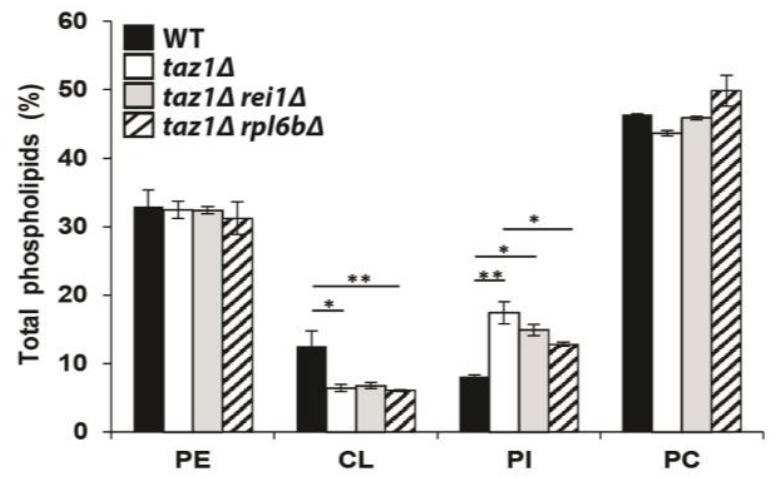

B

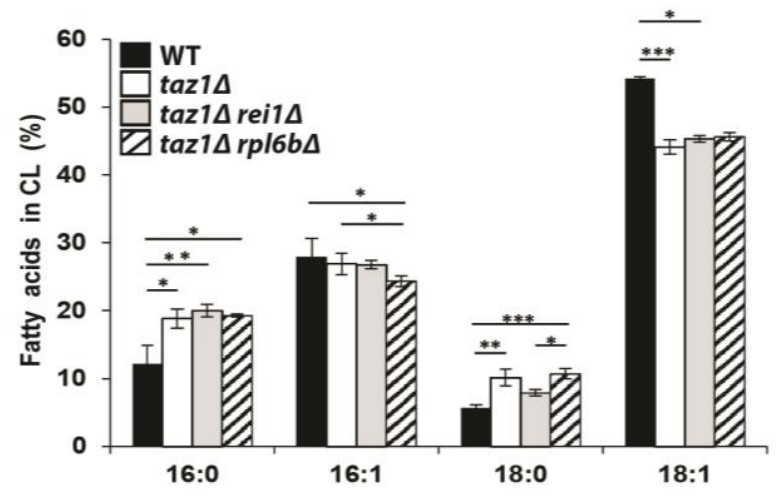

FIGURE 2: Genetic ablation of REI1 or RPL6B in taz1D yeast does not restore cardiolipin remodeling. Lipids were extracted from mitochondria isolated from WT (black bars), $\operatorname{taz} 1 \Delta$ (open bars), taz $1 \Delta$ rei1 $\Delta$ (grey bars) and $\operatorname{taz} 1 \Delta$ rpl6b $\Delta$ (striped bars) cells grown in CSM $0.5 \%$ galactose $+2 \%$ ethanol at $36^{\circ} \mathrm{C}$ until a density of $2-3$ $\mathrm{OD}_{600 \mathrm{~nm}}$. (A) Relative contents of PE (phosphatidylethanolamine), CL (cardiolipin), PI (phosphatidylinositol) and PC (phosphatidylcholine) within each strain. (B) Relative fatty acid chain composition of $C L$ within each strain (16:0, palmitic acid; $16: 1$, palmitoleic acid; 18:0, stearic acid; 18:1: oleic acid). Statistical analysis was done with Kruskal-Wallis test followed by Dunn's multiple comparison test $\left({ }^{*} \mathrm{P}<0.05 ;{ }^{*} \mathrm{P}<0.01 ;{ }^{* * *} \mathrm{P}<0.001\right)$. Data are expressed as mean \pm s.d. $(n=4)$. The data for WT and $\operatorname{taz} 1 \Delta$ strains were reported previously [60].

ShWT1 and ShTazR1 cells (Fig.6 A, B). We took advantage of these differences to test the capacity of $\mathrm{CHX}$ at counteracting the detrimental effects of a lack in $\mathrm{CL}$ maturation in human cells. A large beneficial effect was observed at a 50 pM concentration of $\mathrm{CHX}$. In the experiment shown in Fig. $6 \mathrm{C}$, the drug was added $24-25$ hours after inoculating 200 $\mu \mathrm{l}$ of media with 5000 cells. CHX induced a $48 \mathrm{~h}$ lag phase, after which the cells grew for a long-lasting period of 170 hours, before dying and detaching from their support. In the absence of $\mathrm{CHX}$, death was observed much more rapidly, after 72 hours of continuous growth. At the concentration of $50 \mathrm{pM}, \mathrm{CHX}$ had no effect on the proliferation of ShWT1 (Figure 6D). These observations indicate that a partial decrease in cytosolic translation is, as in taz1 $1 \Delta$ yeast, beneficial to human cells defective in $\mathrm{CL}$ remodeling. 
A

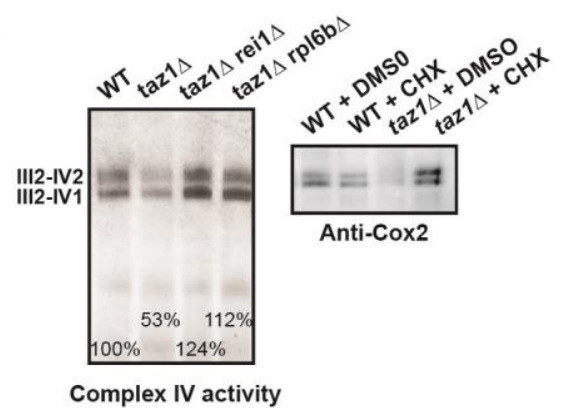

C

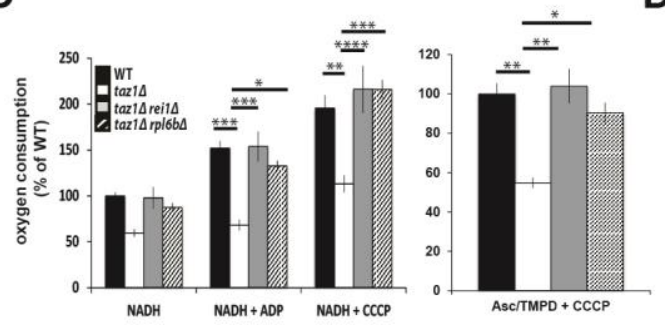

B

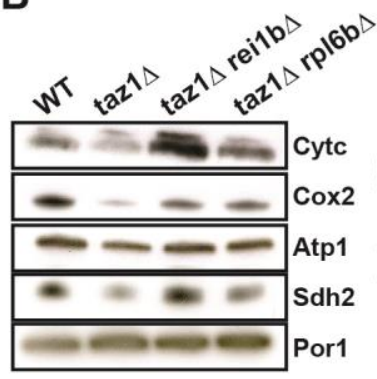

D

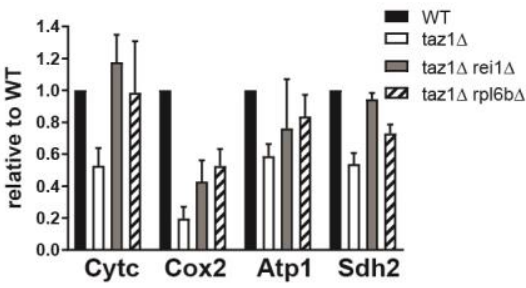

E
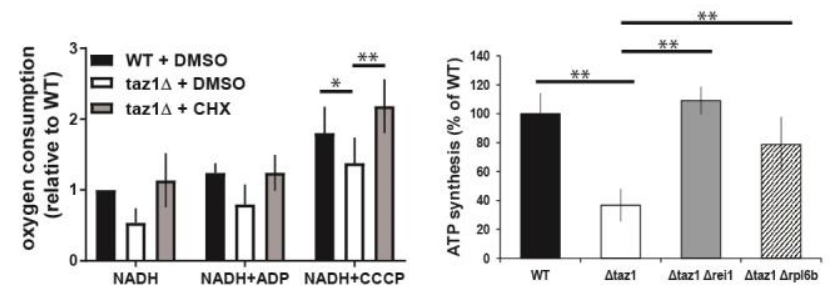

FIGURE 3: Partially decreasing cytosolic translation preserves oxidative phosphorylation in taz1 $\Delta$ yeast. The experiments here described were performed using mitochondria isolated from cells grown for 24 hours at $36^{\circ} \mathrm{C}$ in CSM containing $0.5 \%$ galactose $+2 \%$ ethanol, supplemented or not as indicated with $10 \mathrm{nM} \mathrm{CHX}$, until a density of 2-3 $O D_{600 \mathrm{~nm}}$ (A, B) Steady-state levels of proteins involved in the transfer of electrons to oxygen. (A) Proteins were extracted from the mitochondrial samples using $2 \mathrm{~g}$ digitonin per $\mathrm{g}$ of proteins. The supercomplexes $\mathrm{III}_{2}-\mathrm{IV}_{2}$ and $\mathrm{III}_{2}-\mathrm{IV}_{1}$ were revealed by the complex IV activity after separation by CN-PAGE or by western blot with antibodies against Cox 2 in BN-PAGE gels. (B) Left panel. Total mitochondrial protein samples were resolved by SDS-PAGE (50 $\mu \mathrm{g}$ per lane) and probed with antibodies against the indicated proteins. The shown gels are representative of at least 3 experiments. Right panel. Quantification using ImageJ software. Levels of Cytc, Cox2, Atp1 and Sdh2 are normalized to Por1p and expressed relative to WT. (C) Genetic ablation of REI1 or RPL6B in $\operatorname{taz} 1 \Delta$ yeast preserves mitochondrial respiration. On the left are the rates of oxygen consumption from NADH (4 mM) alone (state 4 ), after further addition $(150 \mu \mathrm{M})$ of ADP (state 3 ) or CCCP $(4 \mu \mathrm{M})$ (uncoupled respiration). The data are expressed in \% of WT state 4 respiration (mean $\pm \mathrm{s} . \mathrm{d}, \mathrm{n}=4)$. On the right are the oxygen consumption rates from electrons delivered directly to complex IV by ascorbate 12.5 $\mathrm{mM}$ /TMPD $1.4 \mathrm{mM}$ in the presence of CCCP. Data are expressed relative to the WT (mean \pm s.d, $n=4$ ). (D) Mitochondrial respiration is preserved in taz1D yeast grown in the presence of $10 \mathrm{nM} \mathrm{CHX.} \mathrm{NADH} \mathrm{was} \mathrm{used} \mathrm{as} \mathrm{the} \mathrm{electron} \mathrm{donor,} \mathrm{as} \mathrm{described} \mathrm{in} \mathrm{panel} \mathrm{C} \mathrm{(} \mathrm{n}=4$ ). (E) ATP synthesis was measured using $\mathrm{NADH}$ as a respiratory substrate in the presence of $1 \mathrm{mM}$ ADP. Data are expressed as mean \pm s.d. ( $\mathrm{n}=4$ ) relative to the WT. The data for WT and $\operatorname{taz} 1 \Delta$ strains were reported previously [60].

\section{DISCUSSION}

While a general inhibition of cytosolic protein synthesis would obviously be detrimental to the cell, our study reveals that a partial (50\%) decrease in this activity preserves mtDNA maintenance and the biogenesis and activity of the oxidative phosphorylation (OXPHOS) system in a yeast model of the Barth syndrome, a mitochondrial disease associated to defects in the remodeling of cardiolipin $(\mathrm{CL})$. The decreased mtDNA stability in taz1 $\Delta$ yeast occurred in fermenting (glucose) cultures where the presence of this DNA is not indispensable. With a respiratory carbon source (glycerol), taz1 $1 \Delta$ yeast cells lacking functional mtDNA were much less abundant owing to their incapacity to proliferate in these conditions. Thus, the respiratory deficiency of $\operatorname{taz} 1 \Delta$ yeast does not result from a lack in mtDNA.

Importantly, $\mathrm{CL}$ remodeling was still deficient in $\operatorname{taz} 1 \Delta$ cells rescued by a partial inhibition of cytosolic translation. This finding has two important corollaries: (i) the $\mathrm{CL}$ species remaining in the mutant ( $50 \%$ vs the WT) are sufficient for a proper biogenesis and functioning of the OXPHOS system, and (ii) the OXPHOS deficit is secondary to some other cellular dysfunction(s) that can be suppressed by de- creasing cytosolic translation. At low concentration (50 pM), CHX also improved proliferation of HeLa cells deficient in tafazzin whereas that of WT Hela cells was not modified, which clearly demonstrates that growth improvement resulted from a compensation of the lack in tafazzin. Thus yeast and human $\mathrm{CL}$ remodeling deficient cells face similar difficulties that can be attenuated by targeting cytosolic translation. These finding reveal that a diminished capacity of $\mathrm{CL}$ remodeling deficient cells to preserve protein homeostasis is likely an important factor contributing to the pathogenesis of the Barth syndrome. This in turn, identifies cytosolic translation as a potential therapeutic target for the treatment of this disease.

Previous work revealed that decreasing cytosolic translation can also rescue yeast models of adPEO (autosomal dominant progressive external ophthalmoplegia) caused by mutations in ANT, a protein that exchanges adenine nucleotides across the mitochondrial inner membrane [68]. In addition to a defective exchange of adenine nucleotides, these mutations compromise the impermeability to protons of the inner membrane. Consequently, a sufficient 

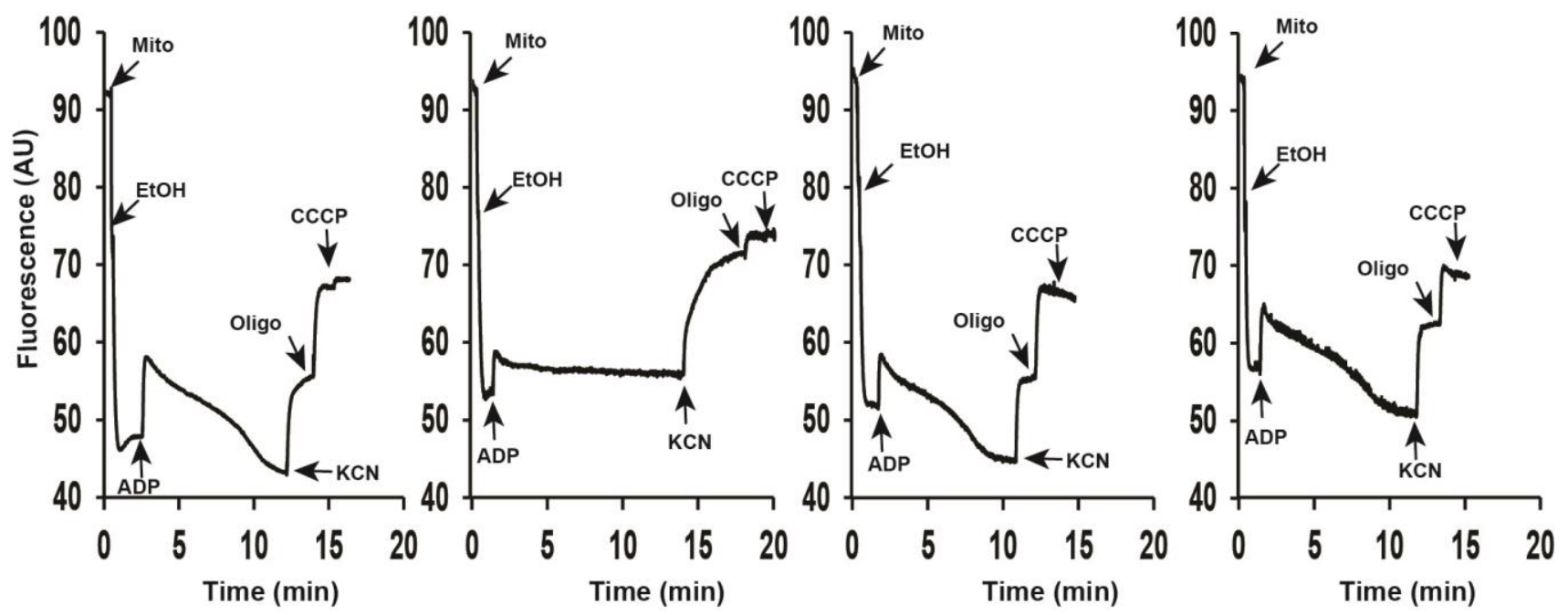

FIGURE 4: Mitochondrial membrane potential. Variations in mitochondrial $\Delta \Psi$ were monitored by fluorescence quenching of Rhodamine 123 , using intact, osmotically-protected, mitochondria isolated from WT, taz1 $1 \Delta$, taz1 $\Delta$ rei1 $\Delta$ and taz $1 \Delta$ rpl6b $\Delta$ cells grown in CSM containing $0.5 \%$ galactose $+2 \%$ ethanol at $36^{\circ} \mathrm{C}$ until a density of $2-3 \mathrm{OD}_{600 \mathrm{~nm}}$. The additions were $75 \mu \mathrm{M} \mathrm{ADP}, 0.5 \mu \mathrm{g} / \mathrm{ml} \mathrm{Rhodamine} 123,75 \mu \mathrm{g} / \mathrm{ml} \mathrm{mi}-$ tochondrial proteins (Mito), $10 \mu \mathrm{l}$ ethanol (EtOH), $2 \mathrm{mM}$ potassium cyanide (KCN), $4 \mu \mathrm{M}$ CCCP (carbonyl cyanide-m-chlorophenyl hydrazone) and $4 \mu \mathrm{g} / \mathrm{ml}$ oligomycin (oligo). The shown tracings are representative of four experimental trials. The data for WT and taz1 $1 \Delta$ strains were reported previously [60].

electrical potential cannot be maintained across this membrane and this impedes many proteins to reach the organelle. This has deleterious consequences, not only for mitochondria, but also for the cytosol that is then confronted with the over-accumulation and the misfolding of mitochondrial precursor proteins [63]. This protein stress, which was termed mitochondrial precursor overaccumulation stress (mPOS), was shown to induce a cellular response, named unfolded protein response activated by mistargeted mitochondrial proteins (UPRam), that is mainly characterized by a decreased rate of cytosolic protein synthesis and a faster rate of protein clearance by the proteasome $[68,69]$. Consistent with these findings, mutations in proteins directly involved in the transport of proteins into mitochondria were found to similarly poison the cytosol with mitochondrial proteins triggering the cell to diminish the production and stimulate the degradation of proteins [69]. The significant drop (35\%) in cytosolic translation in $\operatorname{taz} 1 \Delta$ yeast is an indication that a lack in $\mathrm{CL}$ remodeling could as well lead to the congestion of the cytosol with miss-localized mitochondrial proteins.

Considering the numerous roles of $\mathrm{CL}$ in mitochondria, it might be that a lack in the remodeling of this phospholipid affects the capacity of mitochondria to import proteins, and thereby makes other compartments of the cell more susceptible to protein stress. In support to this hypothesis, loss of $\mathrm{CL}$ remodeling was shown to partially compromise the biogenesis of the protein translocase (TOM) and the sorting and assembly machinery (SAM) of the outer mitochondrial membrane [18, 70]. In another study [36], no evidence was found for a decreased preprotein accumulation in vitro with taz1-deficient mitochondria. However, because these assays used minute amounts of preproteins it might be difficult to detect in this way a partially diminished protein import capacity.

The recovery of mitochondrial function in $\operatorname{taz} 1 \Delta$ yeast by a partial decrease of cytosolic translation is in line with a recent study showing that $\mathrm{CL}$ has an important role in promoting the induction of a mitochondrial-to-cytosolic stress response (MCSR) that enables the cell to improve protein homeostasis in both compartments [71]. Consistently also, it was shown that rapamycin, a specific inhibitor of the mTOR signaling pathway that regulates several extra-mitochondrial cellular pathways among which protein synthesis, robustly enhances survival and attenuates the disease's progression in a mouse model and patient cells of the Leigh Syndrome, one of the most devastating mitochondrial disorders [72, 73].

Clearly, beyond a certain level of mitochondrial damage, the protein stress responsive pathways may not be sufficient. This may explain that in addition to its spontaneous $35 \%$ drop in protein synthesis, $\operatorname{taz} 1 \Delta$ yeast requires a further (15\%) decrease in this activity to be effectively rescued. Whether a general protein synthesis inhibition or a reduced production of specific proteins is beneficial to $\mathrm{CL}$ remodeling deficient cells is an interesting and important issue. In this respect, it is interesting to note that Gerst et al. found that ribosomal protein paralogs specifically modulate translation of mitochondrial precursor proteins [74]. Such observations hold promise for the development of more targeted therapeutic approaches with less undesirable side-effects to preserve protein homeostasis in cells poisoned by the over-accumulation in the cytosol of mitochondrial protein precursors. 


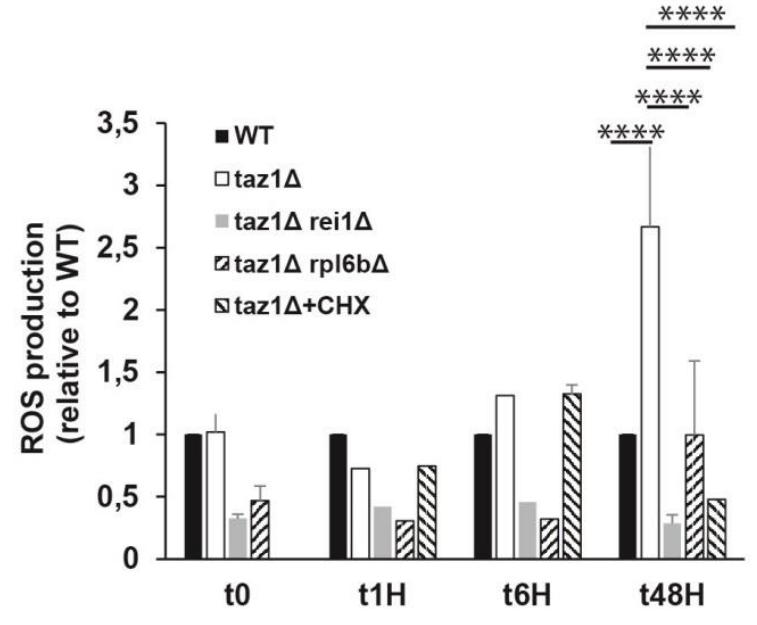

FIGURE 5: Partially decreasing cytosolic translation in taz1A yeast preserves a normal production of ROS. The cells were grown in CSM containing $0.5 \%$ galactose $+2 \%$ ethanol at $36^{\circ} \mathrm{C}$ for 48 hours. At the indicated times, ROS levels were measured by flow cytometry using dihydroethidium as a probe. The data are expressed in \% relative to the WT at TO $(n=3)$. Statistical analysis was done with Tukey's test ( ${ }^{*} \mathrm{P}<0.05 ;{ }^{* *} \mathrm{P}<0.01 ;{ }^{*} * \mathrm{P}<0.001$; $* * * * \mathrm{P}<0.0001)$. The data for WT and $\operatorname{taz} 1 \Delta$ strains were reported previously [60].

\section{MATERIALS AND METHODS \\ Growth media}

The following media were used for growing yeast: Fermentable YPAD media containing $1 \%(\mathrm{w} / \mathrm{v})$ yeast extract, $1 \%(\mathrm{w} / \mathrm{v})$ bacto peptone, $40 \mathrm{mg} / \mathrm{L}$ adenine and $2 \%(\mathrm{v} / \mathrm{v})$ glucose; Respiratory rich media YPAEthanol containing $1 \%(\mathrm{w} / \mathrm{v})$ yeast extract, $1 \%(\mathrm{w} / \mathrm{v})$ bacto peptone, $40 \mathrm{mg} / \mathrm{L}$ adenine and $2 \%(\mathrm{v} / \mathrm{v})$ ethanol; Non-fermentable complete synthetic media $\mathrm{CSM} /$ gal/ethanol containing $0.17 \%(\mathrm{w} / \mathrm{v})$ yeast nitrogen base without aminoacids and ammonium sulfate, $0.5 \%(\mathrm{w} / \mathrm{v}) \mathrm{am}-$ monium sulfate, $0.5 \%(\mathrm{w} / \mathrm{v})$ galactose, $2 \%$ ethanol and $0.08 \%$ $(\mathrm{w} / \mathrm{v})$ of a mixture of aminoacids and bases from Formedium. Solid media contained $2 \%(\mathrm{w} / \mathrm{v})$ agar.

\section{Construction of strains $\operatorname{taz} 1 \Delta \mathrm{rp} / 6 \mathrm{~b} \Delta$ and $\operatorname{taz} 1 \Delta$ rei1 $\Delta$}

These strains were constructed by deleting entirely the open reading frame of RPL6B or REI1 with the KanMX marker using a described procedure [75] in taz1 $\triangle$ mutant (MATa ade2-1 ura3-1 his3-11, 15 trp1-1 leu2-3,112 can1-100, taz1::TRP1). For the construction of the strain $\operatorname{taz} 1 \Delta \operatorname{rp} / 6 b \Delta$, the KanMX cassette was amplified using primers pFA6a-Kan: Rpl6b-del-F (CTT TCT TGA ACT TGG AAG AGA AGC AAA TAT ATT CAA CGA A cgg atc ccc ggg tta att aa) and Rpl6b-del-R (CTA TTT TAA ATC ATT TAT AAT TTT TTC AGT TCA AT gaa ttc gag ctc gtt taa ac) (the sequences in capital letters are homologous to the RPL6B flanking regions, those in lower case enable amplication of $\operatorname{KanMX}$. For the construction of the strain $\operatorname{taz} 1 \Delta$ rei1 $1 \Delta$, the KanMX cassette was amplified with pFA6a-Kan: Rei1-del-F (CAT TAG AAG TCA AGA AGA GAG CAT ATC AGT AAC AAT ACG cgg atc ccc ggg tta attaa) and Rei1-del-R (GCG ACA AAA TAC TAA AAA AAG TAG TGC AAA AAG AA gaa ttc gag ctc gtt taa ac). The primers Rpl6b-Fbis (CTG CGC TTC CGT TCA GCA TC), Rpl6bRbis (CGA TGA CCT GAT CTT GAA CCC) or, Rei1-Fbis (GTG GTG TAG CTA TTT GTA CAT G), and Rei1-Rbis (CAA CAT CTT CAG
TCT TCA GCA GC) were used to verify the deletions of REI1 and $R P L 6 B$ by $P C R$.

\section{Yeast-based drug assay}

0.125 OD of exponentially growing cell were homogeneously spread with sterile glass beads on a square Petri dish $(12 \mathrm{~cm} \mathrm{x}$ $12 \mathrm{~cm}$ ) containing solid YPA ethanol medium. Sterile filters were deposited on the plate and spotted with cycloheximide (purchased from Sigma), anisomycin (purchased from Sigma), and emetine (purchased from Sigma) dissolved in DMSO. Growth improvement was assessed after several days of incubation at $36^{\circ} \mathrm{C}$.

\section{Bioenergetics experiments}

The mitochondria were prepared by the enzymatic method as described [76]. Protein concentrations were determined by the Lowry method [77] in the presence of 5\% SDS. Oxygen consumption rates were measured on $75 \mu \mathrm{g}$ of fresh mitochondria using a Clarke electrode in the respiration buffer (0.65 M mannitol, $0.36 \mathrm{mM}$ ethylene glycol-bis(2aminoethylether)- $\mathrm{N}, \mathrm{N}, \mathrm{N}^{\prime}, \mathrm{N}^{\prime}$-tetraacetic, $5 \mathrm{mM}$ tris-phosphate, $10 \mathrm{mM}$ tris-maleate, $\mathrm{pH}$ 6.8) as described [78] (see legend of Fig. 3 for the concentrations of reagents used). Variations in mitochondrial transmembrane potential $(\Delta \Psi)$ were evaluated in the same respiration buffer, by monitoring the quenching of rhodamine 123 fluorescence $(0.5 \mathrm{mg} / \mathrm{ml})$ using a $\lambda_{\text {exc }}$ of 485 $\mathrm{nm}$ and $\mathrm{a} \lambda_{\text {em }}$ of $525 \mathrm{~nm}$ under constant stirring, using a FLX Spectrofluorimeter (SAFAS, Monaco), as described [79]. ATP synthesis rates were measured using $75 \mu \mathrm{g}$ of fresh mitochondria in a $2-\mathrm{ml}$ thermostatically controlled chamber at $28^{\circ} \mathrm{C}$ in respiration buffer, in the presence of $4 \mathrm{mM} \mathrm{NADH}$ and $1 \mathrm{mM}$ ADP as described [80]. Aliquots were withdrawn from the oxygraph cuvette every 15 seconds and supplemented with $2.5 \%(\mathrm{w} / \mathrm{v})$ perchloric acid, $8.5 \mathrm{mM}$ EDTA to stop the reaction and then neutralized to $\mathrm{pH} 6.8$ by adding $2 \mathrm{~N} \mathrm{KOH}, 0.3 \mathrm{M}$ MOPS. ATP was quantified using a luciferin/luciferase assay (ATPLite kit from Perkin Elmer) on a LKB bioluminometer. The participation of the $F_{1} F_{0}$-ATP synthase in ATP production was assessed using the same protocol, in the presence of oligomy$\operatorname{cin}(3 \mu \mathrm{g} / \mathrm{ml})$.

\section{BN/CN-PAGE \& SDS-PAGE}

Blue native BN-PAGE and clear native CN-PAGE experiments were carried out as described [81], using mitochondrial extracts solubilized with digitonin ( 2 gr per gr protein) run in 3$12 \%$ continuous gradient acrylamide gels. The in-gel complex

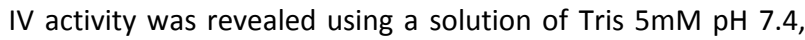
diaminobenzidine $0.5 \mathrm{mg} / \mathrm{ml}$, cytochrome c $0.05 \mathrm{mM}$. The proteins were also analyzed by Western blotting on poly(vinylidene difluoride) membranes as described [82]. Polyclonal antibodies raised against yeast ATP synthase were used at a dilution of 1:50000 for subunit $\alpha$ (gift from J. Velours, IBGC, Bordeaux, France); 1:10000 for cytochrome $c$ (gift from S. Manon, IBGC, Bordeaux, France); 1:5000 for succinate dehydrogenase Sdh2 subunit (gift from C. Dallabona, University of Parma, Italy). Monoclonal antibodies against porin and Cox2 (from Molecular Probes) were used at a dilution of 1:5000. Nitrocellulose membranes were incubated with peroxidase-labeled antibodies (from Promega) at a 1:2500 dilution, and analyzed by electrochemiluminescence. Quantification of the protein signals was performed with the ImageJ software. 
A

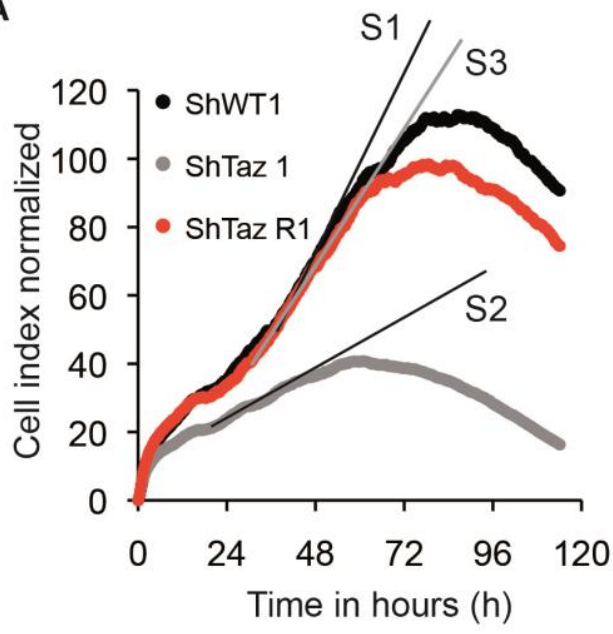

B

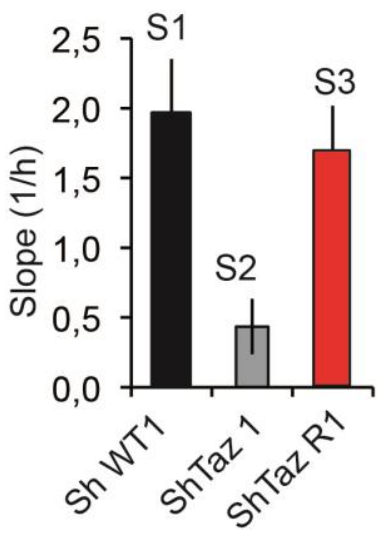

C

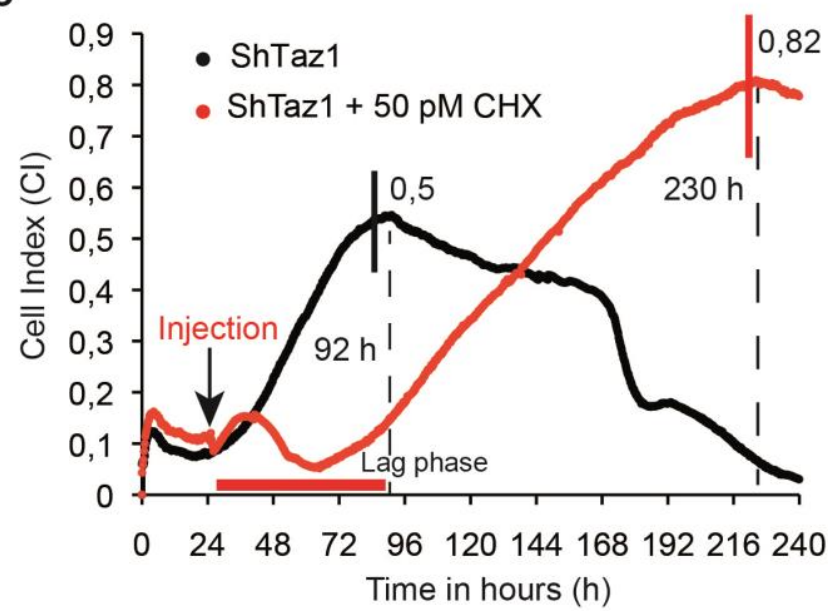

D

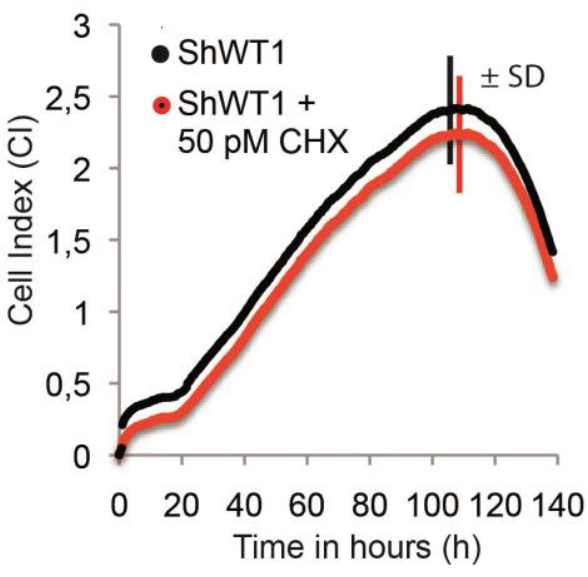

FIGURE 6: CHX improves cell proliferation and viability of human Tafazzin-deficient cells. These experiments used our previously described HeLa cells in which TAZ gene has been knocked down by RNA interference (shTaz1) and two control cell lines, shWT1 and shTaz1R, in which expression of TAZ1 is not inhibited [67]. (A) Growth curves in $200 \mu \mathrm{L}$ wells inoculated with 5000 cells. After reaching a plateau, the cells die and detach from their support. S1, S2 and S3 are the slopes of the proliferation state for each cell lines. (B) Relative slopes (1/h) deduced from the proliferation curves shown in panel A. (C) XCELLigence recording of ShTaz1 proliferation in absence or presence of CHX at a concentration of $50 \mathrm{pM}$. CHX was added (black arrow) after a 24-hour adhesion step. The cultures were inoculated with 5000 cells in $200 \mu \mathrm{L}$ wells. The optimal Cell Index values are indicated along the curves as well as the time (in hours) taken to reach the inflexion point. The horizontal red bar stands for the 48 hours lag phase induced by CHX. Four independent experiments with 4 wells for each growth condition have been done (16 wells in total for establishing mean values). the \pm SD is directly drawn on the top of the curves (in black for ShTaz 1 and in red for SgTaz1 + 50 pM CHX). (D) xCELLigence recording of ShWT1 proliferation in absence or presence of CHX at a concentration of 50 pM. The cultures were inoculated with 5000 cells in $200 \mu \mathrm{L}$ wells. CHX was added before the binding of the cell to the substrate in this case in order to avoid the perturbations induced by the injection of $\mathrm{CHX}$ along the trace; the $\pm \mathrm{SD}$ is directly drawn on the top of the curves (in black for ShWT1 and in red for SgTaz1, there is no significant variation).

\section{In vivo labeling of mitochondrial translation products}

The indicated strains were grown to early exponential phase $(\mathrm{OD} / \mathrm{ml}$ of 2$)$ in $20 \mathrm{ml}$ of rich ethanol/galactose media at $36^{\circ} \mathrm{C}$. The cells were harvested by centrifugation and washed twice with a minimum medium containing $2 \%$ ethanol and $0,5 \%$ galactose, supplemented with histidine, tryptophan, leucine, uracil and adenine (50 mg/liter each). To evaluate total protein synthesis, cells were resuspended in $1 \mathrm{ml}$ of the same medium with the addition of $55 \mu \mathrm{Ci}$ of $\left[{ }^{35} \mathrm{~S}\right]$ methionine plus $\left[{ }^{35} \mathrm{~S}\right]$ cysteine (Amersham Biosciences) and incubated for 20 $\min$ at $36^{\circ} \mathrm{C}$. To evaluate mitochondrial protein synthesis the same procedure was followed but before adding $\left[{ }^{35} \mathrm{~S}\right]$ methio- nine plus $\left[{ }^{35} \mathrm{~S}\right]$ cysteine, cells were first treated with $7,5 \mathrm{mg} / \mathrm{ml}$ cycloheximide during 5 minutes. After the labeling reactions, total protein extracts were prepared and quantified using the Lowry method. The proteins were separated by SDS-PAGE on a $12 \%$ polyacrylamide gel, transferred onto a nitrocellulose membrane and analyzed with a Phosphorlmager. Quantification of radioactive proteins was performed using the software ImageJ [83].

\section{Lipid analyses}

Mitochondrial lipids were analyzed as described [60]. In summary, the lipids were extracted with $2 \mathrm{ml}$ of chloro- 
form/methanol $(2: 1, v / v)$. After centrifugation, the organic phase was isolated and the remaining lipids were further extracted twice by adding $2 \mathrm{ml}$ of chloroform to the aqueous phase. The organic phases were pooled and evaporated to dryness. The lipids were then resuspended in chloroform/methanol $(2: 1, \mathrm{v} / \mathrm{v})$. Respective volumes equivalent to $50 \mu \mathrm{g}$ of acyl chains were spotted on silica plates, four times for each strain. Polar lipids were separated by one dimensional TLC using chloroform/methanol/1-propanol/methyl acetate/0.25\% KCl (10:4:10:10:3.6, by vol.) as a solvent [84]. The lipids were located by immersing the plates in a solution of $0.001 \%(\mathrm{w} / \mathrm{v})$ primuline in PBS, followed by visualization under UV light. The zones of the gel corresponding to $\mathrm{PE}, \mathrm{CL}, \mathrm{PI}$ and $\mathrm{PC}$ were then scraped and added to $1 \mathrm{ml}$ of methanol/2.5\% $\mathrm{H}_{2} \mathrm{SO}_{4}$ containing $5 \mu \mathrm{g}$ of heptadecanoic acid methyl ester as a standard. The lipid mixtures were incubated at $80^{\circ} \mathrm{C}$ for $1 \mathrm{~h}$, and $1.5 \mathrm{ml}$ of water and $400 \mu \mathrm{l}$ of hexane were then added. After centrifugation, the hexane phase containing FAMES (fatty acid methyl esters) was isolated. Separation of FAMES was performed as described [39].

\section{ROS analysis}

Cells at 0.4 OD units were taken from liquid cultures, pelleted in a microcentrifuge, resuspended in $1 \mathrm{ml}$ of phosphatebuffered saline (PBS) containing $50 \mu \mathrm{M}$ dihydroethidium (DHE; Molecular Probes) and incubated at room temperature for 5 min. Flow cytometry was carried out on a Becton-Dickinson Accuri C6 model flow cytometer. The DHE fluorescence indicated was the direct output of the FL2A (red fluorescence) channel without compensation. A total of 100,000 cells were analyzed for each curve.

\section{HeLa cells culture and transfection}

The cervical carcinoma HeLa cell lines were cultured in DME supplemented with $10 \%$ FCS and L- glutamine. Transfection of HeLa cells was performed using Lipofectamine 2000 (Invitrogen). Bcl-xL, shTaz, and shCont stable HeLa cell lines were generated by transfection with pcDNA3/Bcl-xL, pSUPER/shTaz, or pSUPER/shCont, respectively, and selected in G418 [67]. The revertant shTaz1R cell line was generated by cotransfecting shTaz1 HeLa cells with pLpC vector (carrying a puromycin resistance gene), and pcDNA3/Taz mut and stable clones were selected in the presence of puromycin [67].

\section{xCELLigence real time cellular proliferation measurements} Experiments were carried out using the XCELLigence RTCA DP instrument (ACEA Biosciences, Ozyme, France) placed in a humidified incubator at $37^{\circ} \mathrm{C}$ and $5 \% \mathrm{CO}_{2}$. Cell proliferation and cytotoxicity experiments were performed using 16-well plates (E-plate, Ozyme, Montigny le Bretonneux, France). The microelectrodes attached at the bottom of the wells allowed for impedance-based detection of the attachment, spreading and proliferation of the cells. Initially, $180 \mu \mathrm{L}$ of cell-free growth medium (10\% FBS) was added to the wells. After leaving the devices at room temperature for $30 \mathrm{~min}$, the background impedance for each well was measured. Cells were harvested from exponential phase cultures by a standardized detachment procedure using $0.05 \%$ Trypsin-EDTA (Invitrogen). Flow cytometry was used to count the cells and test their viability (FSC versus propidium iodide staining). 5000 or 7500 cells in $20 \mu \mathrm{l}$ were added in each well. After leaving the plates at room temperature for 30 min to allow early cell attachment, in accordance with the manufacturer's guidelines, they were locked in the RTCA DP device in the incubator and the impedance value of each well was automatically monitored by the xCELLigence system and expressed as a Cell Index value (CI). Water was added to the space surrounding the wells of the Eplate to avoid interference from evaporation. For proliferation assays, the cells were incubated during $120 \mathrm{~h}$ for toxicity in growth medium (10\% FBS) and Cl was monitored every 15 min during the whole duration of the experiment. Four replicates of each conditions were used in each test. After an initial assessment of the concentration of cycloheximide which would be non-toxic to the ShWT1 cells, we used a test of proliferation in presence and absence of low doses of cycloheximide (1 $\mathrm{pM}$ to $100 \mathrm{pM}$ ) either prior to cell seeding or after an initial adhesion phase and at an early proliferative step (at 24-26 hours). All experiments were conducted over 240 hours. All plots were normalized to the Cell Index.

\section{AUTHOR CONTRIBUTIONS}

D.T.-T., J.-P.L., M.d.T.d.T. F.G., E.S., R.K, M.B. and P.X. P. performed the experiments; D.T.-T., J.-P.L., J.-P.d.R., M.d.T.d.T. R. K, and E.T. analyzed the data; M.L.G. statistically analyzed the data of Fig. 2; D.T.-T., J.-P.L. and J.-P.d.R designed the research and wrote the paper.

\section{ACKNOWLEDGEMENTS}

We gratefully thank the lipidomic platform of Bordeaux for lipid analysis on the yeast strains and J.J. Bessoule for helpful discussions, and to Emilia Kouroussis for English revisions.

This work was supported by grants from the Association Française contre les Myopathies (AFM) to J.-P.dR and D.T.-T., and P.X.P, the Barth Syndrome Foundation (BSF), Association Barth France to D.T.-T and the Association contre les Maladies Mitochondriales (AMMI) to D.T.-T. M.d.T.d.T. was supported by a PhD fellowship from the French Ministère de l'Enseignement et de la Recherche.

\section{CONFLICT OF INTEREST}

The authors declare no competing or financial interests.

\section{COPYRIGHT}

(C) 2018 de Taffin de Tilques et al. This is an open-access article released under the terms of the Creative Commons Attribution (CC BY) license, which allows the unrestricted use, distribution, and reproduction in any medium, provided the original author and source are acknowledged.

Please cite this article as: Maxence de Taffin de Tilques, Jean-Paul Lasserre, François Godard, Elodie Sardin, Marine Bouhier, Marina Le Guedard, Roza Kucharczyk, Patrice X. Petit, Eric Testet, JeanPaul di Rago, Déborah Tribouillard-Tanvier (2018). Decreasing cytosolic translation is beneficial to yeast and human Tafazzindeficient cells. Microbial Cell 5(5): 220-232. doi: 10.15698/mic2018.05.629 


\section{REFERENCES}

1. Barth PG, Scholte HR, Berden JA, Van der Klei-Van Moorsel JM, Luyt-Houwen IE, Van 't Veer-Korthof ET, Van der Harten JJ, Sobotka-Plojhar MA (1983). An X-linked mitochondrial disease affecting cardiac muscle, skeletal muscle and neutrophil leucocytes. J Neurol Sci 62(1-3): 327-355. doi: 10.1016/0022510X(83)90209-5

2. Barth PG, Valianpour F, Bowen VM, Lam J, Duran M, Vaz FM, Wanders RJ (2004). X-linked cardioskeletal myopathy and neutropenia (Barth syndrome): an update. Am J Med Genet A 126A(4): 349-354. doi: 10.1002/ajmg.a.20660

3. Bolhuis PA, Hensels GW, Hulsebos TJ, Baas F, Barth PG (1991). Mapping of the locus for X-linked cardioskeletal myopathy with neutropenia and abnormal mitochondria (Barth syndrome) to Xq28. Am J Hum Genet 48(3): 481-485. PMID: 1998334

4. Hoch FL (1992). Cardiolipins and biomembrane function. Biochim Biophys Acta 1113(1): 71-133. doi: 10.1016/03044157(92)90035-9

5. Schlame M, Haldar D (1993). Cardiolipin is synthesized on the matrix side of the inner membrane in rat liver mitochondria. J Biol Chem 268(1): 74-79. PMID: 8380172

6. Schlame M, Rua D, Greenberg ML (2000). The biosynthesis and functional role of cardiolipin. Prog Lipid Res 39(3): 257-288. doi: 10.1016/S0163-7827(00)00005-9

7. Ikon N, Su B, Hsu FF, Forte TM, Ryan RO (2015). Exogenous cardiolipin localizes to mitochondria and prevents TAZ knockdown-induced apoptosis in myeloid progenitor cells. Biochem Biophys Res Commun 464(2): 580-585. doi: 10.1016/j.bbrc.2015.07.012

8. Bligny R, Douce R (1980). A precise localization of cardiolipin in plant cells. Biochim Biophys Acta 617(2): 254-263. doi: 10.1016/0005-2760(80)90168-X

9. Hostetler KY, van den Bosch H, van Deenen LL (1972). The mechanism of cardiolipin biosynthesis in liver mitochondria. Biochim Biophys Acta 260(3): 507-513. doi: 10.1016/00052760(72)90065-3

10. Joshi AS, Zhou J, Gohil VM, Chen S, Greenberg ML (2009). Cellular functions of cardiolipin in yeast. Biochim Biophys Acta 1793(1): 212-218. doi: 10.1016/j.bbamcr.2008.07.024

11. Bazan S, Mileykovskaya E, Mallampalli VK, Heacock P, Sparagna GC, Dowhan W (2013). Cardiolipin-dependent reconstitution of respiratory supercomplexes from purified Saccharomyces cerevisiae complexes III and IV. J Biol Chem 288(1): 401-411. doi: 10.1074/jbc.M112.425876

12. Pfeiffer K, Gohil V, Stuart RA, Hunte C, Brandt U, Greenberg $\mathrm{ML}$, Schagger $H$ (2003). Cardiolipin stabilizes respiratory chain supercomplexes. J Biol Chem 278(52): 52873-52880. doi: 10.1074/jbc.M308366200

13. Zhang M, Mileykovskaya E, Dowhan W (2002). Gluing the respiratory chain together. Cardiolipin is required for supercomplex formation in the inner mitochondrial membrane. J Biol Chem 277(46): 43553-43556. doi: 10.1074/jbc.C200551200

14. Joshi AS, Thompson MN, Fei N, Huttemann M, Greenberg ML (2012). Cardiolipin and mitochondrial phosphatidylethanolamine have overlapping functions in mitochondrial fusion in Saccharomyces cerevisiae. J Biol Chem 287(21): 17589-17597. doi: 10.1074/jbc.M111.330167
15. Ban T, Heymann JA, Song Z, Hinshaw JE, Chan DC (2010). OPA1 disease alleles causing dominant optic atrophy have defects in cardiolipin-stimulated GTP hydrolysis and membrane tubulation. Hum Mol Genet 19(11): 2113-2122. doi: 10.1093/hmg/ddq088

16. DeVay RM, Dominguez-Ramirez L, Lackner LL, Hoppins S, Stahlberg H, Nunnari J (2009). Coassembly of Mgm1 isoforms requires cardiolipin and mediates mitochondrial inner membrane fusion. J Cell Biol 186(6): 793-803. doi: 10.1083/jcb.200906098

17. Jiang $F$, Ryan $M T$, Schlame $M$, Zhao $M$, Gu Z, Klingenberg $M$, Pfanner N, Greenberg ML (2000). Absence of cardiolipin in the crd1 null mutant results in decreased mitochondrial membrane potential and reduced mitochondrial function. J Biol Chem 275(29): 22387-22394. doi: 10.1074/jbc.M909868199

18. Gebert N, Joshi AS, Kutik S, Becker T, McKenzie M, Guan XL, Mooga VP, Stroud DA, Kulkarni G, Wenk MR, Rehling P, Meisinger C, Ryan MT, Wiedemann N, Greenberg ML, Pfanner N (2009). Mitochondrial cardiolipin involved in outer-membrane protein biogenesis: implications for Barth syndrome. Curr Biol 19(24): 2133-2139. doi: 10.1016/j.cub.2009.10.074

19. Patil VA, Fox JL, Gohil VM, Winge DR, Greenberg ML (2013). Loss of cardiolipin leads to perturbation of mitochondrial and cellular iron homeostasis. J Biol Chem 288(3): 1696-1705. doi: 10.1074/jbc.M112.428938

20. Chu CT, Bayir H, Kagan VE (2014). LC3 binds externalized cardiolipin on injured mitochondria to signal mitophagy in neurons: implications for Parkinson disease. Autophagy 10(2): 376-378. doi: 10.4161/auto.27191

21. Chu CT, Ji J, Dagda RK, Jiang JF, Tyurina YY, Kapralov AA, Tyurin VA, Yanamala N, Shrivastava IH, Mohammadyani D, Qiang Wang $\mathrm{KZ}$, Zhu J, Klein-Seetharaman J, Balasubramanian K, Amoscato AA, Borisenko G, Huang Z, Gusdon AM, Cheikhi A, Steer EK, Wang R, Baty C, Watkins S, Bahar I, Bayir H, Kagan VE (2013). Cardiolipin externalization to the outer mitochondrial membrane acts as an elimination signal for mitophagy in neuronal cells. Nat Cell Biol 15(10): 1197-1205. doi: 10.1038/ncb2837

22. Hsu P, Liu X, Zhang J, Wang HG, Ye JM, Shi Y (2015). Cardiolipin remodeling by TAZ/tafazzin is selectively required for the initiation of mitophagy. Autophagy 11(4): 643-652. doi: 10.1080/15548627.2015.1023984

23. Li XX, Tsoi B, Li YF, Kurihara H, He RR (2015). Cardiolipin and its different properties in mitophagy and apoptosis. J Histochem Cytochem 63(5): 301-311. doi: 10.1369/0022155415574818

24. Gonzalvez F, D'Aurelio M, Boutant M, Moustapha A, Puech JP, Landes T, Arnaune-Pelloquin L, Vial G, Taleux N, Slomianny C, Wanders RJ, Houtkooper RH, Bellenguer P, Moller IM, Gottlieb E, Vaz FM, Manfredi G, Petit PX (2013). Barth syndrome: cellular compensation of mitochondrial dysfunction and apoptosis inhibition due to changes in cardiolipin remodeling linked to tafazzin (TAZ) gene mutation. Biochim Biophys Acta 1832(8): 1194-1206. doi: 10.1016/j.bbadis.2013.03.005

25. Heit B, Yeung T, Grinstein S (2011). Changes in mitochondrial surface charge mediate recruitment of signaling molecules during apoptosis. Am J Physiol Cell Physiol 300(1): C33-41. doi: 10.1152/ajpcell.00139.2010

26. Kim TH, Zhao Y, Ding WX, Shin JN, He X, Seo YW, Chen J, Rabinowich $H$, Amoscato AA, Yin XM (2004). Bid-cardiolipin interaction at mitochondrial contact site contributes to 
mitochondrial cristae reorganization and cytochrome $\mathrm{C}$ release. Mol Biol Cell 15(7): 3061-3072. doi: 10.1091/mbc.E03-12-0864

27. Manganelli V, Capozzi A, Recalchi S, Signore M, Mattei V, Garofalo T, Misasi R, Degli Esposti M, Sorice M (2015). Altered Traffic of Cardiolipin during Apoptosis: Exposure on the Cell Surface as a Trigger for "Antiphospholipid Antibodies". J Immunol Res 2015:847985. doi: 10.1155/2015/847985

28. McMillin JB, Dowhan W (2002). Cardiolipin and apoptosis. Biochim Biophys Acta 1585(2-3): 97-107. doi: 10.1016/S13881981(02)00329-3

29. Koshkin V, Greenberg ML (2000). Oxidative phosphorylation in cardiolipin-lacking yeast mitochondria. Biochem J 347 Pt 3:687691. doi: 10.1042/bj3470687

30. Koshkin V, Greenberg ML (2002). Cardiolipin prevents ratedependent uncoupling and provides osmotic stability in yeast mitochondria. Biochem J 364(Pt 1): 317-322. doi: 10.1042/bj3640317

31. Kadenbach B, Mende P, Kolbe HV, Stipani I, Palmieri F (1982). The mitochondrial phosphate carrier has an essential requirement for cardiolipin. FEBS Lett 139(1): 109-112. doi: 10.1016/00145793(82)80498-5

32. Robinson NC (1993). Functional binding of cardiolipin to cytochrome c oxidase. J Bioenerg Biomembr 25(2): 153-163. doi: $10.1007 /$ bf00762857

33. Noel H, Pande SV (1986). An essential requirement of cardiolipin for mitochondrial carnitine acylcarnitine translocase activity. Lipid requirement of carnitine acylcarnitine translocase. Eur J Biochem 155(1): 99-102. doi: 10.1111/j.14321033.1986.tb09463.x

34. Vaz FM, Houtkooper RH, Valianpour F, Barth PG, Wanders RJ (2003). Only one splice variant of the human TAZ gene encodes a functional protein with a role in cardiolipin metabolism. J Biol Chem 278(44): 43089-43094. doi: 10.1074/jbc.M305956200

35. Gu Z, Valianpour F, Chen S, Vaz FM, Hakkaart GA, Wanders RJ, Greenberg ML (2004). Aberrant cardiolipin metabolism in the yeast taz1 mutant: a model for Barth syndrome. Mol Microbiol 51(1): 149-158. doi: 10.1046/j.1365-2958.2003.03802.x

36. Brandner K, Mick DU, Frazier AE, Taylor RD, Meisinger C, Rehling $P$ (2005). Taz1, an outer mitochondrial membrane protein, affects stability and assembly of inner membrane protein complexes: implications for Barth Syndrome. Molecular biology of the cell 16(11): 5202-5214. doi: 10.1091/mbc.E05-03-0256

37. Neuwald AF (1997). Barth syndrome may be due to an acyltransferase deficiency. Curr Biol 7(8): R465-466. doi: 10.1016/s0960-9822(06)00237-5

38. Xu Y, Kelley RI, Blanck TJ, Schlame M (2003). Remodeling of cardiolipin by phospholipid transacylation. J Biol Chem 278(51): 51380-51385. doi: 10.1074/jbc.M307382200

39. Testet E, Laroche-Traineau J, Noubhani A, Coulon D, Bunoust O, Camougrand N, Manon S, Lessire R, Bessoule JJ (2005). Ypr140wp, 'the yeast tafazzin', displays a mitochondrial lysophosphatidylcholine (lyso-PC) acyltransferase activity related to triacylglycerol and mitochondrial lipid synthesis. Biochem J 387(Pt 3): 617-626. doi: 10.1042/BJ20041491

40. Ren $M$, Phoon CK, Schlame M (2014). Metabolism and function of mitochondrial cardiolipin. Prog Lipid Res 55(1-16. doi: 10.1016/j.plipres.2014.04.001
41. Sickmann A, Reinders J, Wagner Y, Joppich C, Zahedi R, Meyer HE, Schonfisch B, Perschil I, Chacinska A, Guiard B, Rehling P, Pfanner N, Meisinger C (2003). The proteome of Saccharomyces cerevisiae mitochondria. Proc Natl Acad Sci U S A 100(23): 1320713212. doi: 10.1073/pnas.2135385100

42. Vreken P, Valianpour F, Nijtmans LG, Grivell LA, Plecko B, Wanders RJ, Barth PG (2000). Defective remodeling of cardiolipin and phosphatidylglycerol in Barth syndrome. Biochem Biophys Res Commun 279(2): 378-382. doi: 10.1006/bbrc.2000.3952

43. Schlame M, Kelley RI, Feigenbaum A, Towbin JA, Heerdt PM, Schieble T, Wanders RJ, DiMauro S, Blanck TJ (2003). Phospholipid abnormalities in children with Barth syndrome. J Am Coll Cardiol 42(11): 1994-1999. doi: doi.org/10.1016/j.jacc.2003.06.015

44. Valianpour F, Mitsakos V, Schlemmer D, Towbin JA, Taylor JM, Ekert PG, Thorburn DR, Munnich A, Wanders RJ, Barth PG, Vaz FM (2005). Monolysocardiolipins accumulate in Barth syndrome but do not lead to enhanced apoptosis. J Lipid Res 46(6): 1182-1195. doi: 10.1194/jlr.M500056-JLR200

45. Ferri L, Donati MA, Funghini S, Malvagia S, Catarzi S, Lugli L, Ragni L, Bertini E, Vaz FM, Cooper DN, Guerrini R, Morrone A (2013). New clinical and molecular insights on Barth syndrome. Orphanet J Rare Dis 8:27. doi: 10.1186/1750-1172-8-27

46. Gonzalvez F, Gottlieb E (2007). Cardiolipin: setting the beat of apoptosis. Apoptosis 12(5): 877-885. doi: 10.1007/s10495-0070718-8

47. Dudek J, Cheng IF, Balleininger M, Vaz FM, Streckfuss-Bomeke K, Hubscher D, Vukotic M, Wanders RJ, Rehling P, Guan K (2013). Cardiolipin deficiency affects respiratory chain function and organization in an induced pluripotent stem cell model of Barth syndrome. Stem Cell Res 11(2): 806-819. doi: 10.1016/j.scr.2013.05.005

48. Xu Y, Sutachan JJ, Plesken H, Kelley RI, Schlame M (2005). Characterization of lymphoblast mitochondria from patients with Barth syndrome. Lab Invest 85(6): 823-830. doi 10.1038/labinvest.3700290

49. Steinmetz LM, Scharfe C, Deutschbauer AM, Mokranjac D, Herman ZS, Jones T, Chu AM, Giaever G, Prokisch H, Oefner PJ, Davis RW (2002). Systematic screen for human disease genes in yeast. Nat Genet 31(4): 400-404. doi: 10.1038/ng929

50. Reinders J, Zahedi RP, Pfanner N, Meisinger C, Sickmann A (2006). Toward the complete yeast mitochondrial proteome: multidimensional separation techniques for mitochondrial proteomics. J Proteome Res 5(7): 1543-1554. doi: 10.1021/pr050477f

51. Prokisch H, Scharfe C, Camp DG, 2nd, Xiao W, David L, Andreoli C, Monroe ME, Moore RJ, Gritsenko MA, Kozany C, Hixson KK, Mottaz HM, Zischka H, Ueffing M, Herman ZS, Davis RW, Meitinger T, Oefner PJ, Smith RD, Steinmetz LM (2004). Integrative analysis of the mitochondrial proteome in yeast. PLoS Biol 2(6): e160. doi: 10.1371/journal.pbio.0020160

52. Pagliarini DJ, Calvo SE, Chang B, Sheth $S A$, Vafai SB, Ong SE, Walford GA, Sugiana C, Boneh A, Chen WK, Hill DE, Vidal M, Evans JG, Thorburn DR, Carr SA, Mootha VK (2008). A mitochondrial protein compendium elucidates complex I disease biology. Cell 134(1): 112-123. doi: 10.1016/j.cell.2008.06.016

53. Rhee HW, Zou P, Udeshi ND, Martell JD, Mootha VK, Carr SA, Ting AY (2013). Proteomic mapping of mitochondria in living cells 
via spatially restricted enzymatic tagging. Science 339(6125): 1328-1331. doi: 10.1126/science.1230593

54. Bonnefoy N, Fox TD (2001). Genetic transformation of Saccharomyces cerevisiae mitochondria. Methods Cell Biol 65:381-396. doi: 10.1016/s0091-679x(01)65022-2

55. Tzagoloff A, Dieckmann CL (1990). PET genes of Saccharomyces cerevisiae. Microbiol Rev 54(3): 211-225. PMID: 2215420

56. Baile MG, Claypool SM (2013). The power of yeast to model diseases of the powerhouse of the cell. Front Biosci 18:241-278. doi: $10.2741 / 4098$

57. Lasserre JP, Dautant A, Aiyar RS, Kucharczyk R, Glatigny A, Tribouillard-Tanvier D, Rytka J, Blondel $M$, Skoczen N, Reynier $P$, Pitayu L, Rotig A, Delahodde A, Steinmetz LM, Dujardin G, Procaccio V, di Rago JP (2015). Yeast as a system for modeling mitochondrial disease mechanisms and discovering therapies. Dis Model Mech 8(6): 509-526. doi: 10.1242/dmm.020438

58. Couplan E, Aiyar RS, Kucharczyk R, Kabala A, Ezkurdia N, Gagneur J, St Onge RP, Salin B, Soubigou F, Le Cann M, Steinmetz LM, di Rago JP, Blondel M (2011). A yeast-based assay identifies drugs active against human mitochondrial disorders. Proc Natl Acad Sci U S A 108(29): 11989-11994. doi: 10.1073/pnas. 1101478108

59. Ostojic J, Panozzo C, Lasserre JP, Nouet C, Courtin F, Blancard C, di Rago JP, Dujardin G (2013). The energetic state of mitochondria modulates complex III biogenesis through the ATPdependent activity of Bcs1. Cell Metab 18(4): 567-577. doi: 10.1016/j.cmet.2013.08.017

60. de Taffin de Tilques M, Tribouillard-Tanvier D, Tetaud E, Testet E, di Rago JP, Lasserre JP (2017). Overexpression of mitochondrial oxodicarboxylate carrier (ODC1) preserves oxidative phosphorylation in a yeast model of Barth syndrome. Dis Model Mech 10(4): 439-450. doi: 10.1242/dmm.027540

61. Aiyar RS, Bohnert M, Duvezin-Caubet S, Voisset C, Gagneur J, Fritsch ES, Couplan E, von der Malsburg K, Funaya C, Soubigou F, Courtin F, Suresh S, Kucharczyk R, Evrard J, Antony C, St Onge RP, Blondel M, di Rago JP, van der Laan M, Steinmetz LM (2014). Mitochondrial protein sorting as a therapeutic target for ATP synthase disorders. Nat Commun 5:5585. doi: 10.1038/ncomms6585

62. Baile MG, Sathappa M, Lu YW, Pryce E, Whited K, McCaffery JM, Han X, Alder NN, Claypool SM (2014). Unremodeled and remodeled cardiolipin are functionally indistinguishable in yeast. J Biol Chem 289(3): 1768-1778. doi: 10.1074/jbc.M113.525733

63. Wang X, Zuo X, Kucejova B, Chen XJ (2008). Reduced cytosolic protein synthesis suppresses mitochondrial degeneration. Nat Cell Biol 10(9): 1090-1097. doi: 10.1038/ncb1769

64. Lebreton A, Saveanu C, Decourty L, Rain JC, Jacquier A, Fromont-Racine $M$ (2006). A functional network involved in the recycling of nucleocytoplasmic pre-60S factors. J Cell Biol 173(3): 349-360. doi: $10.1083 / \mathrm{jcb} .200510080$

65. Chen $S, H e Q$, Greenberg ML (2008). Loss of tafazzin in yeast leads to increased oxidative stress during respiratory growth. Mol Microbiol 68(4): 1061-1072. doi: 10.1111/j.13652958.2008.06216.x

66. Acehan D, Xu Y, Stokes DL, Schlame M (2007). Comparison of lymphoblast mitochondria from normal subjects and patients with
Barth syndrome using electron microscopic tomography. Lab Invest 87(1): 40-48. doi: 10.1038/labinvest.3700480

67. Gonzalvez F, Schug ZT, Houtkooper RH, MacKenzie ED, Brooks DG, Wanders RJ, Petit PX, Vaz FM, Gottlieb E (2008). Cardiolipin provides an essential activating platform for caspase-8 on mitochondria. The Journal of cell biology 183(4): 681-696. doi: 10.1083/jcb.200803129

68. Wang X, Chen XJ (2015). A cytosolic network suppressing mitochondria-mediated proteostatic stress and cell death. Nature 524(7566): 481-484. doi: 10.1038/nature14859

69. Wrobel L, Topf U, Bragoszewski P, Wiese S, Sztolsztener ME, Oeljeklaus S, Varabyova A, Lirski M, Chroscicki P, Mroczek S, Januszewicz E, Dziembowski A, Koblowska $M$, Warscheid $B$, Chacinska A (2015). Mistargeted mitochondrial proteins activate a proteostatic response in the cytosol. Nature 524(7566): 485-488. doi: 10.1038/nature14951

70. Sauerwald J, Jores T, Eisenberg-Bord M, Chuartzman SG, Schuldiner M, Rapaport D (2015). Genome-Wide Screens in Saccharomyces cerevisiae Highlight a Role for Cardiolipin in Biogenesis of Mitochondrial Outer Membrane Multispan Proteins. Mol Cell Biol 35(18): 3200-3211. doi: 10.1128/MCB.00107-15

71. Kim HE, Grant AR, Simic MS, Kohnz RA, Nomura DK, Durieux J, Riera CE, Sanchez M, Kapernick E, Wolff S, Dillin A (2016). Lipid Biosynthesis Coordinates a Mitochondrial-to-Cytosolic Stress Response. Cell 166(6): 1539-1552 e1516. doi 10.1016/j.cell.2016.08.027

72. Johnson SC, Yanos ME, Kayser EB, Quintana A, Sangesland M, Castanza A, Uhde L, Hui J, Wall VZ, Gagnidze A, Oh K, Wasko BM, Ramos FJ, Palmiter RD, Rabinovitch PS, Morgan PG, Sedensky MM, Kaeberlein $M$ (2013). mTOR inhibition alleviates mitochondrial disease in a mouse model of Leigh syndrome. Science 342(6165): 1524-1528. doi: 10.1126/science.1244360

73. Zheng $X$, Boyer L, Jin $M$, Kim $Y$, Fan W, Bardy C, Berggren $T$, Evans RM, Gage FH, Hunter T (2016). Alleviation of neuronal energy deficiency by mTOR inhibition as a treatment for mitochondria-related neurodegeneration. Elife 5: e13378. doi: 10.7554/eLife.13378

74. Segev N, Gerst JE (2018). Specialized ribosomes and specific ribosomal protein paralogs control translation of mitochondrial proteins. The Journal of cell biology 217(1): 117-126. doi: 10.1083/jcb.201706059

75. Longtine MS, McKenzie A, 3rd, Demarini DJ, Shah NG, Wach A, Brachat A, Philippsen P, Pringle JR (1998). Additional modules for versatile and economical PCR-based gene deletion and modification in Saccharomyces cerevisiae. Yeast 14(10): 953-961. doi: YEA293>3.0.CO;2-U 10.1002/(SICI)1097-0061(199807)14:10<953::AID-

76. Guerin B, Labbe P, Somlo M (1979). Preparation of yeast mitochondria (Saccharomyces cerevisiae) with good $\mathrm{P} / \mathrm{O}$ and respiratory control ratios. Methods Enzymol 55(149-159. doi: 10.1016/0076-6879(79)55021-6

77. Lowry OH, Rosebrough NJ, Farr AL, Randall RJ (1951). Protein measurement with the Folin phenol reagent. J Biol Chem 193(1): 265-275. PMID: 14907713

78. Rigoulet M, Guerin B (1979). Phosphate transport and ATP synthesis in yeast mitochondria: effect of a new inhibitor: the tribenzylphosphate. FEBS Lett 102(1): 18-22. doi: 10.1016/00145793(79)80919-9 
79. Emaus RK, Grunwald R, Lemasters JJ (1986). Rhodamine 123 as a probe of transmembrane potential in isolated rat-liver mitochondria: spectral and metabolic properties. Biochim Biophys Acta 850(3): 436-448. doi: 10.1016/0005-2728(86)90112-

\section{$x$}

80. Rak M, Tetaud E, Godard F, Sagot I, Salin B, Duvezin-Caubet S, Slonimski PP, Rytka J, di Rago JP (2007). Yeast cells lacking the mitochondrial gene encoding the ATP synthase subunit 6 exhibit a selective loss of complex IV and unusual mitochondrial morphology. J Biol Chem 282(15): 10853-10864. doi: 10.1074/jbc.M608692200

81. Schagger $H$, von Jagow $G$ (1991). Blue native electrophoresis for isolation of membrane protein complexes in enzymatically active form. Anal Biochem 199(2): 223-231. doi: 10.1016/00032697(91)90094-a
82. Arselin G, Vaillier J, Graves PV, Velours J (1996). ATP synthase of yeast mitochondria. Isolation of the subunit $h$ and disruption of the ATP14 gene. J Biol Chem 271(34): 20284-20290. doi: 10.1074/jbc.271.34.20284

83. Gassmann M, Grenacher B, Rohde B, Vogel J (2009) Quantifying Western blots: pitfalls of densitometry. Electrophoresis 30(11): 1845-1855. doi: 10.1002/elps.200800720

84. Vitiello F, Zanetta JP (1978). Thin-layer chromatography of phospholipids. J Chromatogr 166(2): 637-640. doi: 10.1016/s0021-9673(00)95654-1 